\title{
WN-8 (シデリア)について
}

\section{1. 概 説}

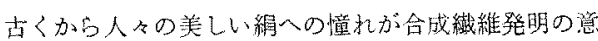
欲をかきたて，今日の合瀻畤代が築かれるに至ったこと

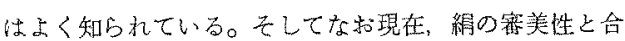

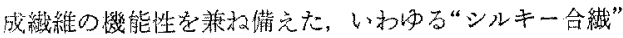
が次々と開登され，ボりアミド，ボリエステル，ポりフ クリロニトリルといった分野から，それそれの性能を生

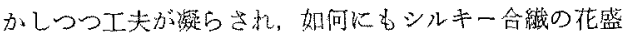

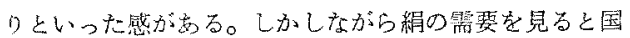
内でこを增加し続外ているが，こ扎老世界的に見た場 台、絹の生虐量はすで頭打らの状態で嵓って, 特に米

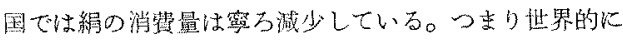

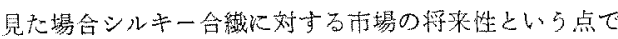

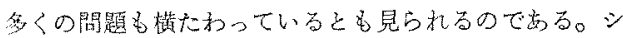

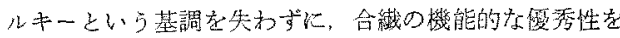

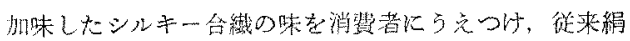

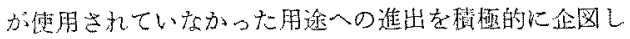
なければならないなど，かなりの努力が必瑟な時期とな っている

ところでシルキ一台瀻としては現状では，乙の物性面 からポりエステル，ポりフクリロニトリルから出愽した

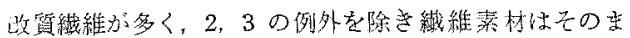
杰にし，断面形態墨形断面としてシルキ一にしよらと している。しかしこれら笚一素材ではシルキーな一部の

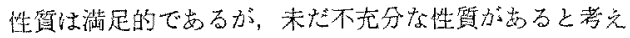
ている。例えば和装着尺では腰が㤝すきるとか，染色の

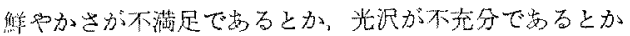

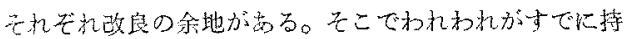
っている複合技術を生かしてポリエステルとポリアミド から出笔し、これに鮮やか染色性と、しなやかでンフ トなタッチ，さらに一層優雅な深味の无炕沢を持たせ

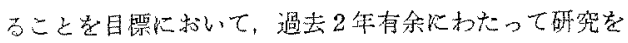

WN-8 (Sideria)

SATOSHI ANDO

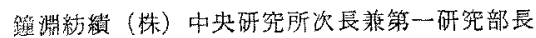

安

藤

聰
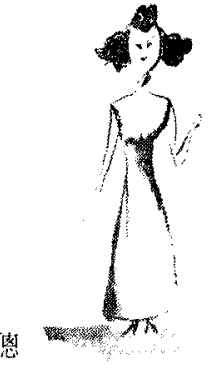

重ね、ここにWN-8(シデリア) を発表するに至ったの だある。

WN-8 の特徴は

(1) シルクライクである

(2) 染色方美しい

(3) 茹が活る

（4）报い易い瀻維で㟔る

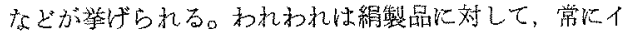
ニシャチブをとり繶けてをているし，われわれが絹製品 取扱いに長年の経験さ持っている。それだけに最る編以

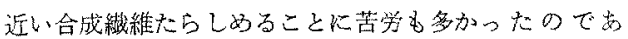
万。

以下をの性能见ついて頊を追って紹介したい。

\section{2. $\mathbf{W N}-8$ の 構 造}

ポリアミド系ポリマーとポリエステル禾ポリマーが, 第 1 四の一例に示すよりに二重構造となったマルキポり マー纎踓でする。

WN-8 虫勒がポリアミド，芯がポリエステルよりな

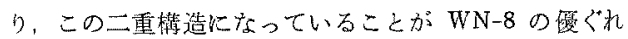
た性能を示守要因となっている。二重構造に和ける芯の 形状はク口ーバ形，六鱼星形，三铜形など適宜变光るこ よができこれれよって性能に変化をむたしている。

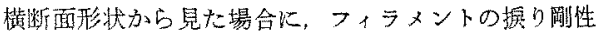

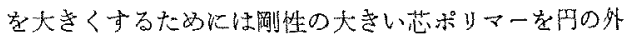

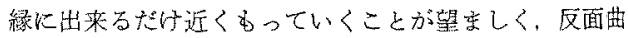
げ岡性を大さくするたるには，莎ポリマーを三角形状に 近くもっていくことが望ましいので患る。WN-8の断面

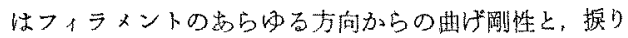
践性を調和させながら舅も大きくするたるに有利な形状
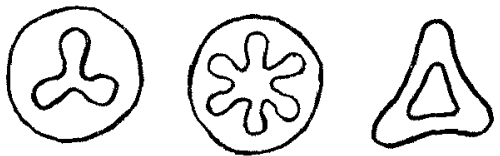

第1图 WN-8フタライント断面の一例 
となっている。これ炕よって実用上，ポリエステル程便 すぎることなく、ナイロン程策らかすぎるとがなく、 ちようど絹のよらに程良い岡性を与えているのでせる。 同時にまたこれこそ最も重要なことであるがここの

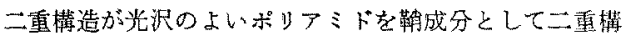
造による光の乱屈折を最す適㓜儿利用し，優雅な深味の ある光沢を与をてい。

WN-8は，円形断面或いは巽形断面である。市中のシ ルキー合緎では光沢の度合を強くするといら理由で殆ん どが異形断面でする。WN-8の場合も目的とする光沢度 合に応して，異形断面をとっている。しかしWN-8で は二成分間に屈折率の差があり，しか子鞂ポリマーが光 沢の良いポリアミドになっているた，円形断面でる朩 らかく陑雅な光沢が得られる。光沢に対する二重權造の

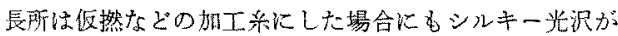
失われ難い点である。ポリエスデル或いはナイロンの如 く単一素材で汪，たとえ異形断面の昜合でる加工によ。 て断面がく机易く，加况て巻縮のため光沢の消失加太

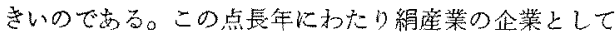

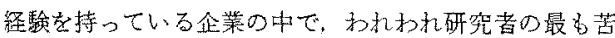

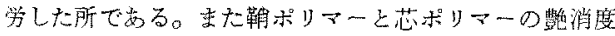

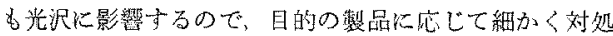
している。

WN-8は唱質が常に均斉に得られること，二雚分の長 所が明瞭比現かれ易い等の有利性がある。例点ば触感で は芯ポりマーであるポりエステルの特性が表面にあで現 われて䳬のポリアミドの性質で方る好的り感を消してし

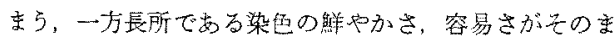
ま残るなど，編織構造物上しての実用性から見て二成分 のそれぞれの長所が，現的短所がくれてしま。てい 万。

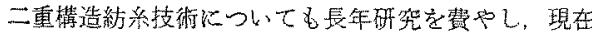

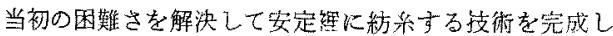
ている。

\section{WN-8 の一般系筫}

WN-8の一般系筫第1表火示す。

ヤング率蛙のヤング䔞に近く，ポリェステルよりも 低い。この点ポリエステルのようにヤング率が高，硬 くて身体机フィッしにくいるいら短所を完全に力パー している。特に和装品ではこの点が重要なポイントの一

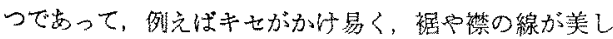
く出るなど着物としての形体的審美性が侵くれたすのに なる。の点から見てWN-8 るが和装品として邀切な 性能を持っているとい方る。第2国火应力伸張明線吉示 す。
第 1 表 WN-8の一般性質

\begin{tabular}{|c|c|c|c|c|c|}
\hline 項 & 目 & WN-8 & 編 & $\begin{array}{l}\text { ポりエ } \\
\text { テ㘳 }\end{array}$ & +102 \\
\hline 強度 & 影 & $4.5 \sim 6.0$ & $3.0 \sim 4.0$ & $4.3 \sim 5.5$ & $4.8 \sim 6.4$ \\
\hline$(g / d)$ & 湿 & $4.2 \sim 5.5$ & $2.1 \sim 2.8$ & $4.3 \sim 5.5$ & $4.2 \sim 5.9$ \\
\hline 伸度 & 晖 & $20 \sim 32$ & $15 \sim 25$ & $20 \sim 32$ & \\
\hline$(\%)$ & 湿 & $22 \sim 34$ & $27 \sim 33$ & $20 \sim 32$ & $36 \sim 52$ \\
\hline $\begin{array}{r}+\% 9 \\
(\mathrm{~kg} / \mathrm{c} \\
5 \% / \mathrm{ht}\end{array}$ & & & & & \\
\hline $\begin{array}{l}5 \% \text { 伸 } \\
\text { 性度 }\end{array}$ & & $98 \sim 100$ & $60 \sim 70$ & $95 \sim 97$ & $97 \sim 9$ \\
\hline 地 & 雷 & 1.20 & 1.32 & 1.38 & 1.14 \\
\hline 熱水収 & & $6 \sim 18$ & $1 \sim$ & $5 \sim 10$ & $8 \sim 22$ \\
\hline 酸 光 & 制 & 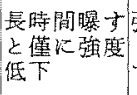 & $\begin{array}{l}\text { 強度低下著 } \\
\text { L6。60日日 } \\
\text { で55\%低下 }\end{array}$ & $\begin{array}{l}\text { 長時間曝吉 } \\
\text { 嚾以。强度 } \\
\text { 低下。 }\end{array}$ & 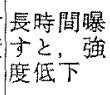 \\
\hline 桇 盖 & 性 & 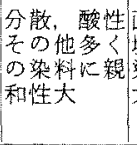 & 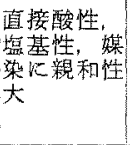 & 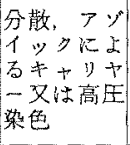 & $\begin{array}{l}\text { 分散, 酸 } \\
\text { 性之の他 } \\
\text { 多くの染 } \\
\text { 料に親和 } \\
\text { 性大 }\end{array}$ \\
\hline
\end{tabular}

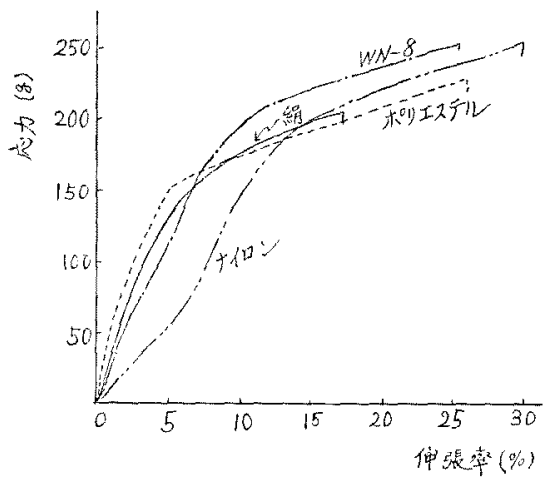

第 2 图応力一伸長曲線

第 2 表 WN-8フイランントの伸張弹性荤

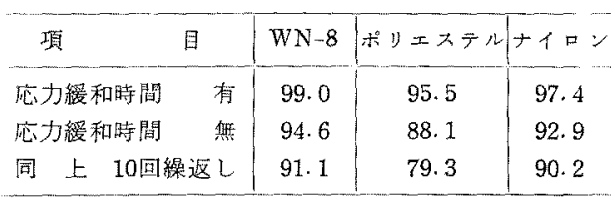

WN-80伸張弾性は編織物としての憔能に関係のある

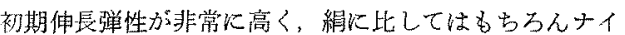
ロンポリエステルよりも高い。例党ば $5 \%$ 伸張弾珄にお ける応力緩和時間 2 分と応力緩和を与充ない場合括よび 応力緩和を与えないで 10 回繰泛した場合の伸張弾珄率 学胃ると第 2 袁の如くなる。

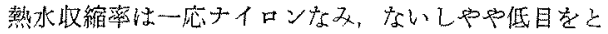



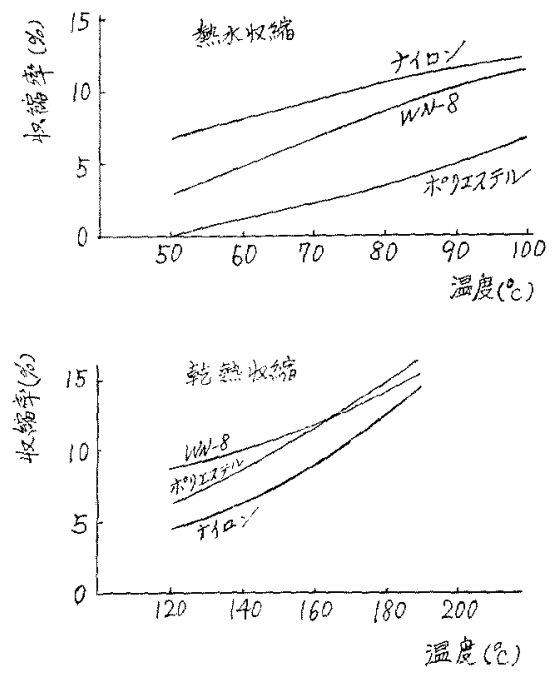

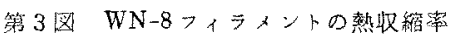

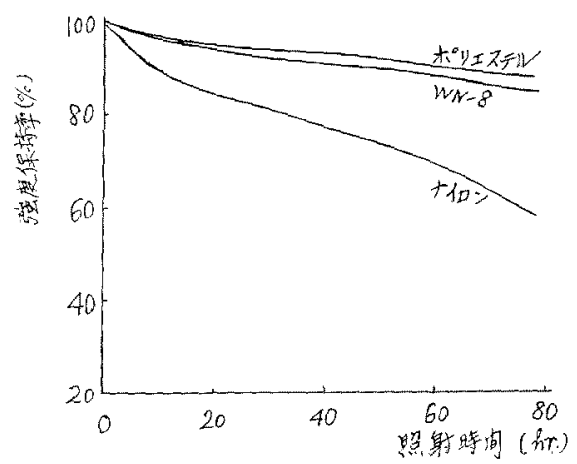

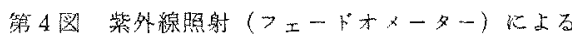
强度変化

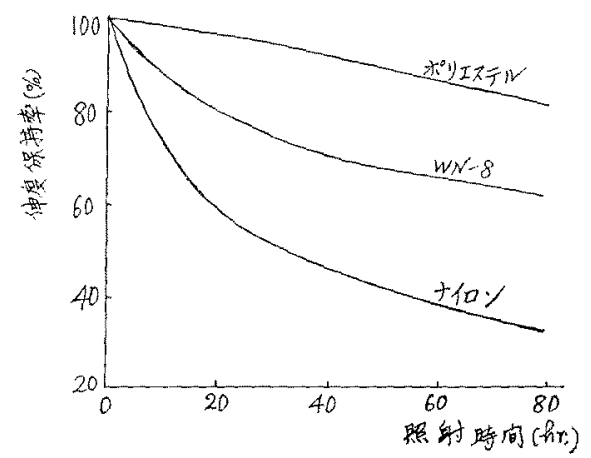

第 5 図 紫外線照射（フェードオャーター）に上る 伸度变化
っている。当ちろん加工舫比すればこの值は小さくなる ことは当然である。各温度に拈ける WN-8 の熱水収維

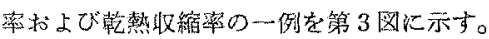

耐光性については強度保持率は，大略ポリエステルK 近く，伸度保持率はナイロンとポりエステルの中間程度

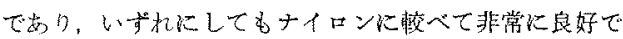

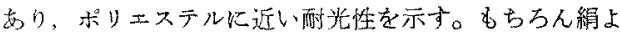

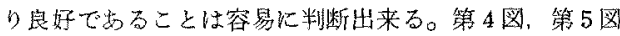
で比較なる。

染着性については分散、酸栍，含金，クロムその他多

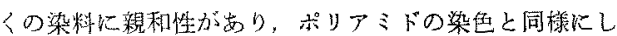

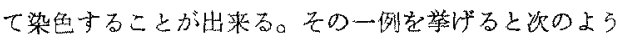
な涌常の酸性染料に上る染法で，鮮やかな色相に染色す ることができる。

染料 Coomassie Ultra Sky SE 3\% o.w.f

助剂 Acetic Acid $3 \%$ o.w.f

浴比 $1: 50$

温䇺

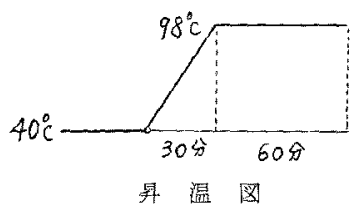

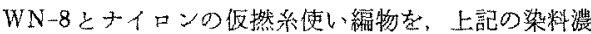
磨索克て染色し，GE社㹕のスペクトロフォトメータ 一によって全反射率曲線を比較した結果を第 6 図に示 $+$

染料澧度が同濃签の埸合 WN-8 の表面はオイロン単 独系同デニールのbのより高濃度に染まっている管で あるが，反射率曲線で性ナイロンに比しやや高い位㯰に

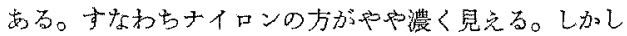
この場合染料灙度を調整することによって反射率曲線の

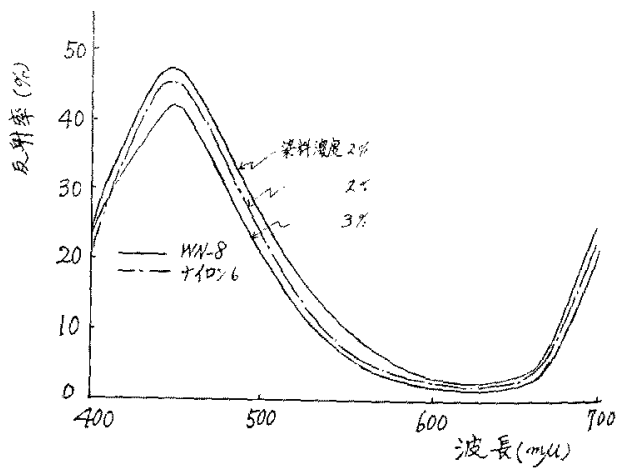

第 6 图WN-8架色物の全反射曲緗 
第 3 表 $\mathrm{WN}-8$ の酸性染料染色堅审度の一例

\begin{tabular}{|c|c|c|c|c|c|c|}
\hline \multirow{2}{*}{ 染 } & \multicolumn{2}{|c|}{ 洗たく } & 晹 & 洗 & \multirow{2}{*}{ 酸光 } & \\
\hline & 䇛息 & 污染 & 绝 & 活染 & & \\
\hline Erio Fast Blue $2 \mathrm{GL}$ & 5 & 4 & 5 & 3 & 5 以上 & 5 \\
\hline Xylen Light Yellow & 5 & 5 & 5 & 4 & 5 以上 & 5 \\
\hline Telon Red BL & 5 & 5 & 5 & 4 & 5 以上 & 5 \\
\hline
\end{tabular}

应置袁变えることができ，肉眼上濃出たすることが容易 に可能で方る。もるるん染料を選九で染着率を上げ曲線 の位置を下げることは容易で方る。染色の堅牢性は良好

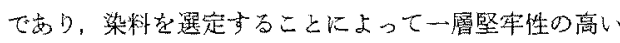

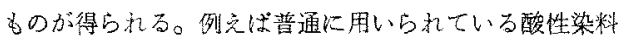
て染め大場合の染色㯺安第 3 表に示卞。

このよらに容易に鮮やかに染色出来ることは、シルキ 一合纎として最も必要な性能の一つをWN-8 が范分满 足させていることになる。加士上特に問題になる染也传

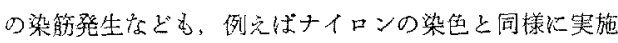
しても染差加発生するよらなトラブルは起らず, その他

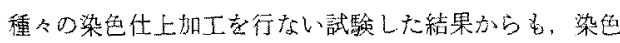

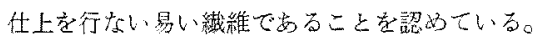

\section{WN-8 の加工䅈について}

仮然加工，バンロン加工など简高加工はナイロンを同

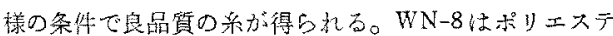
ルやナイロンに比して，線としてはCR 健が小さくなる

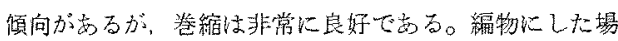
合特にストレッチパックが強く、これはナイロン6.6よ りも臨ぐれている。WN-8加工糸使いの特数はこのス卜 レッチパックの强さ比むるとい光る。

第7图にWN-8，ナイロン6敊よびナイロン6.6の仮

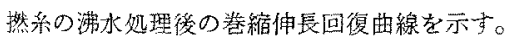

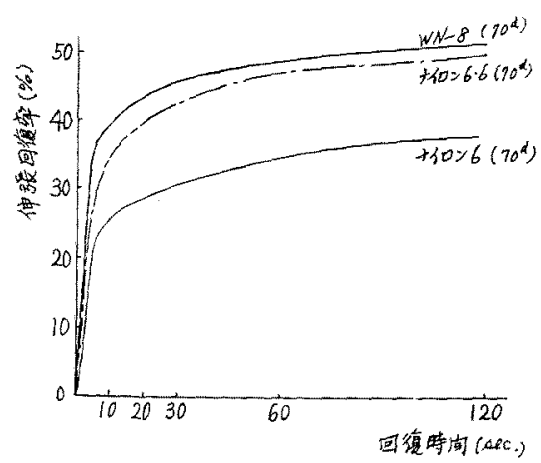

第 7 因WN-8仮热系の巻縮伸張回復曲線

\section{WN-8 の䌟織物について}

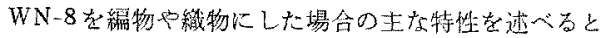

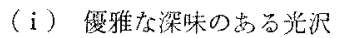

(ii）鯶やが色相比染色でるる

(iii) 柔㳄な弾力女るタッキとドレープ

(iv) 好り感がない

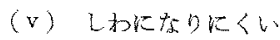

(vi) プリーツ性が良い

などで名が，編物の場合ストレッチはナイロン程大き くないが，ストレッチバッタが非常に良いなどの性筫が 加交られる。ベンロン系による同仕様のフルファッショ

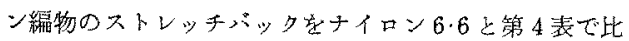
船与去。

WN-8はナイロン6.6より名伸張弹性度が筒く，伸張

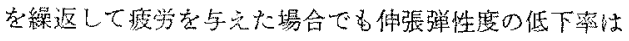
ナイロン6.6よりも小さい。この編物を水中に浸漬して 十分に湿濯させ七同样汇測定した場合も，ナイロン 6.6

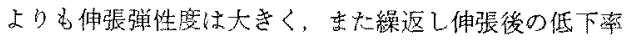
手小でかる。

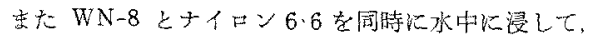
同様に軽く機械探み劣した場合，編地性张したが，乙 の伸び染はナイロン6.6の約 1/5 前後であることも認め られている。

第 4 表 WN-8編物口保腲弹性

\begin{tabular}{|c|c|c|c|}
\hline 項 & 目 & WN -8 & †1 $\Rightarrow 26.6$ \\
\hline \multirow{2}{*}{ 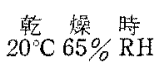 } & 掩垤 1 回 $(\%)$ & 95 & 93 \\
\hline & 伸镸10回 $(\%)$ & 90 & 85 \\
\hline \multirow{2}{*}{ 湿 潤 侍 } & 伸㖘1回 $(\%)$ & 93 & 89 \\
\hline & 伸張10回 $(\%)$ & 89 & 79 \\
\hline
\end{tabular}

第 5 㘪WN-8織物の一般特性

\begin{tabular}{|c|c|c|c|c|}
\hline 愐 目 & $W N-8$ & $\begin{array}{l}\text { 我リ工 } \\
\text { ステル }\end{array}$ & 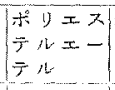 & $\begin{array}{l}x y>z \\
\text { y } a=r \\
\text { y } 2\end{array}$ \\
\hline 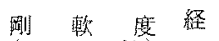 & 38 & 45 & 38 & 43 \\
\hline (クラーク法) 緯 & 40 & 42 & 46 & 41 \\
\hline ドレープ性 \%) & 34 & 35 & 33 & 32 \\
\hline \multirow{4}{*}{ 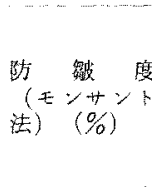 } & 94 & 90 & 90 & 92 \\
\hline & 82 & 84 & 85 & 83 \\
\hline & 88 & 92 & 87 & 85 \\
\hline & 78 & 84 & 83 & 75 \\
\hline 沢 & $\begin{array}{l}\text { 柔らか心 } \\
\text { 絧样光沢 }\end{array}$ & 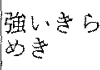 & 強いきら & $\begin{array}{l}\text { 深みのb } \\
\text { る兆沢 }\end{array}$ \\
\hline 触 & シャり時 & シャ当味 & ジ+リ味 & シャ味味 \\
\hline
\end{tabular}


このようにWN-8 の編物は，着用した場合変形しに くい。特湿润時例克ば雨に需孔た場合にす伸びてだら

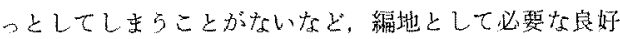

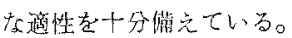

次に織物としての一般的特性の一例を同組織の他瀻維 織物と比較して第 5 表に举げる。

ポリエステルやポリエステルエーテルに比してソフト

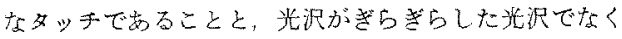

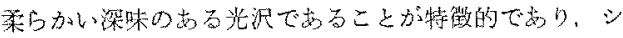
ルキーといらことで非常に隤机ていることがわかる。

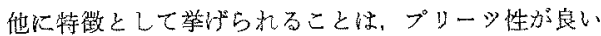
ことである。例壳ば WN-8 のマットウース織物でポり エステルとプリーシ性を比較方ると，洗たく後 AATCC 法による試駩結果では洗たく 5 回俊WN-8は4級であ りボリメステルは4.5級であった。杰た同様 W\&W 性

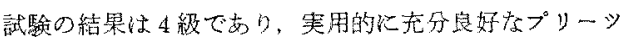
性を有し，虫たWＷW 性織物として使用できる。この よ5にWN-8は機能性に要んだ取扱い易いシルキ一合

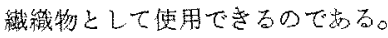

\section{WN-8 の主要商品}

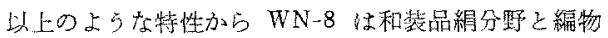
整品への济品化ぶ主体となる。

現在生産されている種粯は $30,50 ， 75$ デニールであ

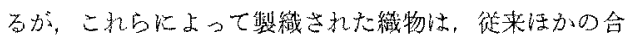
瀻では出し得ないシルキーな炕沢，手螌り，儑雅なドレ ープ, 取报いやすい機能性を発揮している。

織物，とくに和茎シルキー用途では，織組緎としては 平羽二重、綾羽二重，サテンサテンタレープ、デシン シフォン、ジョーゼットなど多岐にわたり, 駒偷子, 平 偷子，とんす，一越縮面などの着尺や羽尺，八掛胴豪な

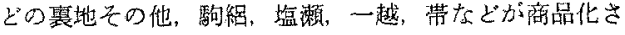
れ，またスカーフ類も商品化されている。宋た金地とし ても遁性があり，プリントが鮮明で，しかもプリント時 に生地の伸びが発生けず，附光性が良いこと，繰返し折 りたたみによってかてる目ずれやビンホールが登生しに くいなどの特徽がある。さらに羊毛との交織で性加工上 の容易さだけで度く，商晶としても非常にニニークな風 合を出すことが出来，この方面にもかなりの量が伸びて 行くものと考充ている。

しかし WN-8 のシルキーライタは和装品との他織物 にの文道性があるわけではない。製編された編物俚その シルキーな外锶に加えて，特他加工系として使用する㙋 合に，ストレッ回復に儤ぐれていること，湿满時炕型 くずれが少ないこと、欢り箵がないことなどで高砐二

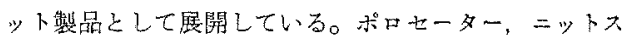
ーッ, ハイダージブシウス，シンダルジャージ，ダブル ジヤージなど仮撚やパンロン使いで厦ぐれた嘀品化がな されている。

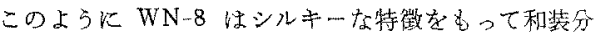
野，婦人物，二ット分野へ罢開しているが，将莱紳士服

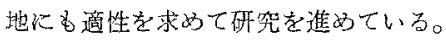

\section{7. ま Ł か}

今までに述べたよらに WN-8は長年の研究藏月を鿓

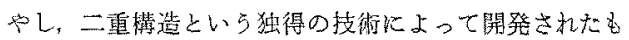

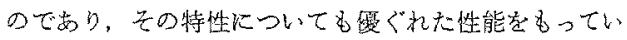
る。しかし今後実際に商品化流虂の段階で各種の問题点

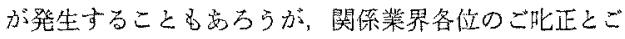

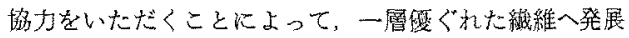
していくことを望んでいる。 